\title{
Hoary cress reproduction in a sagebrush ecosystem
}

\author{
LARRY LARSON, GARY KIEMNEC, AND TERESA SMERGUT
}

Authors are professor Department of Rangeland Resources, associate professor Department of Crop and Soil Science, and graduate research assistant at time of research Department of Rangeland Resources, Oregon State University, Corvallis, Ore. 97331.

\begin{abstract}
Field studies were undertaken to evaluate hoary cress (Cardaria draba (L.) Desv.) reproduction and spread in a sagebrush ecosystem. Hoary cress germination, emergence, and survival were restricted to moist environments. These conditions occurred 2 out of 8 years. Hoary cress germination under field conditions was greatest on toe slope positions and areas of soil disturbance. Number of shoots varied annually for established hoary cress populations. Shoot propagation was reduced when early spring growth was followed by frost or drought. Shoot numbers were increased when spring growth was delayed and warm, moist growing conditions occurred in May. Seed reproduction did not increase plant density in monitored populations. Established populations relied upon vegetative reproduction to sequester resources and increase plant density.
\end{abstract}

Key Words: Noxious weeds, Cardaria draba (L.) Desv., rangeland weeds

Hoary cress (Cardaria draba (L.) Desv.), also known as whitetop or heart-podded whitetop, was introduced to North America in the 1800's (Mulligan and Franklin 1962). The earliest collections of hoary cress in the United States were made in California in 1876 (Groh 1940). Hoary cress, a perennial weed of forage crops, has extended its range into the sagebrush ecosystem of the Northern Great Basin.

Hoary cress reproduces by seed and creeping rootstock (Whitson et al. 1992). Two seeds develop in each heart-shaped capsule. Adult plants can produce 1,200 to 4,800 seed with over $80 \%$ viability (Selleck 1965). Seed rain occurs as individual seeds are released through ruptures in the capsule sidewall, as individual capsules, and as capsule clusters which break away from the parent plant. Hoary cress seed exude mucilage when moistened (Kiemnec and Larson 1991). Mucilage produced by other species increases germination under conditions of low osmotic potential (0 to $-0.2 \mathrm{MPa}$ ) (Harper and Benton 1966). Germination occurs in the fall or spring and non-germinated seed can remain viable in the soil seed bank for 3 to 4 years (Bellue 1946, Pryor 1959). Shoots develop on adult plants at the root crown and along creeping root stock (Mulligan and Findlay 1974). Shoot development begins in the fall or spring, as a loose rosette, and culminates with the production of a flowering stalk.

Understanding the expression of reproductive characteristics of hoary cress in a sagebrush ecosystem would aid in the evaluation

Manuscript accepted 25 Nov. 1999.
Resumen

Se condujeron estudios de campo para evaluar la reproducción y diseminación de "Hoary cress" [Cardaria draba (L.) Desv.] en un ecosistema de "Sagebrush". La germinación, emergencia y sobrevivencia de "Hoary cress" ocurrió solo en ambientes húmedos. Estas condiciones se presentaron en 2 de 8 años. La germinación de "Hoary cress" bajo condiciones de campo fue mayor en posiciones de la punta de la pendiente y en áreas con suelo disturbado. En las poblaciones establecidas de "Hoary cress", el número de tallos varió anualmente. La propagación de los tallos se redujo cuando el crecimiento temprano de primavera fue seguido de una sequía o helada. El número de tallos se incremento cuando el crecimiento de primavera se retrasó y en Mayo se presentaron condiciones de calor y humedad. La reproducción por semilla no incrementó la densidad de plantas en las poblaciones establecidas. Las poblaciones establecidas dependieron mas de la reproducción vegetativa para adquirir los recursos necesarios e incrementar la densidad de plantas.

of its spreading potential. The objective of this research was to evaluate the contribution of vegetative and seed reproduction to hoary cress spread in a sagebrush ecosystem by measuring germination, emergence and shoot density.

\section{Materials and Methods}

Field studies were conducted between 1986 and 1994 in northeastern Oregon $\left(44^{\circ} 43^{\prime} \mathrm{N}, 117^{\circ} 45^{\prime} \mathrm{W}\right)$ in the foothill range of the Wallowa mountains. Study sites lie within the Wyoming big sagebrush (Artemisia tridentata ssp wyomingensis Nutt.)—bluebunch wheatgrass (Agropyron spicatum (Pursh) Scribn. \& Smith = Pseudoroegneria spicata (Pursh) Scribn. \& Smith) habitat type (Daubenmire 1970). At each study site the sagebrush component was intact but the bluebunch wheatgrass had been lost and later replaced by crested wheatgrass (A. cristatum (L.) Gaertn.) seeded during the 1960's. The predominant soil in the study area is an Encina gravelly silt loam (fine, montmorillonitic, mesic Aridic Calcic Argixeroll).

Temperature and precipitation data obtained from the Baker City airport (10 k from study area, 1,050 m elevation) were used to calculate average precipitation $(\mathrm{mm})$, maximum/minimum temperature (C) and growing degree day (Miller and Donahue 1990) estimates (threshold: $4^{\circ} \mathrm{C}$ ). Precipitation and temperature frequency estimates were obtained from the Baker County Soil Survey (Laird et al. 1988) and represent data recorded in the period 1951 to 1981 . 


\section{Seed reproduction - germination}

Hoary cress seed was collected at the study area during July 1988. Seed were separated from capsules, cleaned and counted into lots of 50. Shriveled seed was discarded. Each lot (50 seed) was sealed with $5 \mathrm{ml}$ of silt loam soil in a nylon mesh packet $(8 \mathrm{~cm} \times 8 \mathrm{~cm}$; mesh opening $=$ $0.015 \mathrm{~cm}$ ) and placed in the field in October 1988.

Seed packets were located in 4 topographic positions (ridgetop, toe slope, mid-slope north aspect, and mid-slope south aspect). Seed packets were placed on the surface and at 1- and 3-cm depths and were retrieved at 6-week intervals beginning on 15 December 1988 and ending on 1 May 1989. Each treatment was replicated 5 times (4 topographic positions, 3 soil depths, 4 retrieval dates, 5 replicates $=240$ seed packets/experiment). The experiment was conducted at 2 sites within the study area.

Seed packets were opened on the retrieval date and number of germinated seed (emerged radicle) recorded. Remaining seeds were placed on filter paper moistened with distilled water in a sealed Petri dish and placed in an environmental chamber (16-hour dark period at $15^{\circ} \mathrm{C}, 8$-hour light period at $20^{\circ} \mathrm{C}$ ). Germination was evaluated for 16 days with germination counts occurring at 4day intervals.

Data analyses were performed on 2 categories of seed germination: (1) field germinated seed-seeds germinated in the seed packet prior to the retrieval dates of 15 December, 1 February, 15 March, and 1 May and (2) total germination-seeds germinated in the field plus seeds germinated in the environmental chamber after each retrieval date. Data from the 2 sites were combined after it was determined there were no site differences. The experimental design was a complete randomized block. Data analysis (Dowdy and Wearden 1983) included Hartley's data normality test, analysis of variance, and mean separation by least significant difference $(\mathrm{P} \leq 0.05)$.

\section{Seed reproduction - emergence}

Hoary cress emergence was studied at 2 sites in 1986 and 1987. Seed were collected in July 1986 and 1987 using the procedures described previously. Seed were broadcast (50 seed/plot) in November 1986 and 1987 onto $0.1-\mathrm{m}^{2}$ plots in both Wyoming sagebrush-crested wheatgrass and annual grass communities (toe slope topographic position). Tilled (churned with a shovel) and undisturbed seedbed treatments were compared in a complete

randomized block design. Treatments were replicated 3 times within each community at each site ( 2 years, 2 sites, 2 treatments, 3 replications). Emerged seedlings were counted at weekly intervals in May 1987 and 1988. Emergence data were analyzed using analysis of variance procedures with mean separation by least significant difference $(\mathrm{P} \leq 0.05)$. Data were blocked by years, and sites were combined after it was determined that there were no site differences.

\section{Vegetative reproduction}

Hoary cress shoot density was estimated by counting live shoots along 8 permanent transects (30-m length) in 2 infested Wyoming big sagebrush-crested wheat-

Table 1. Field germination of hoary cress seed associated with topographic position and soil depth.

\begin{tabular}{|c|c|c|c|c|}
\hline \multirow[b]{2}{*}{ Position } & \multicolumn{3}{|c|}{ Soil Depth $(\mathrm{cm})$} & \multirow[b]{2}{*}{ Mean } \\
\hline & 0 & 1 & 3 & \\
\hline & \multicolumn{4}{|c|}{ - } \\
\hline Toe slope & $56 \mathrm{c}$ & $43 \mathrm{~b}$ & $34 \mathrm{a}$ & $45 \mathrm{C}$ \\
\hline North Aspect & $16 \mathrm{a}$ & $34 \mathrm{c}$ & $28 \mathrm{~b}$ & $26 \mathrm{~B}$ \\
\hline Ridgetop & $19 \mathrm{a}$ & $27 \mathrm{~b}$ & $26 \mathrm{~b}$ & $24 \mathrm{~B}$ \\
\hline South Aspect & $6 \mathrm{a}$ & $16 \mathrm{~b}$ & $20 \mathrm{c}$ & $14 \mathrm{~A}$ \\
\hline
\end{tabular}

${ }^{\mathrm{T}}$ Horizontal letter changes indicate significance (LSD = 4; P $\leq 0.05$ )within a topographic position. Upper case letters indicate significance of means across topographic positions ( $\mathrm{LSD}=6 ; \mathrm{P} \leq 0.05$ ).

grass communities. Parallel transects were established at each infestation (diameter approximately $70 \mathrm{~m}$ ); 2 transects dissected the infestation and 2 transects (non-infested) were tangent to the infestation. Shoot densities were tallied mid-May from 1987 through 1994. Density counts were taken using $0.2-\mathrm{m}^{2}$ quadrats placed at $1.5 \mathrm{~m}$ intervals along the transect. Data were not collected in 1991.

Twenty excavations $\left(0.25 \mathrm{~m}^{2}\right.$ X $20 \mathrm{~cm}$ deep) within hoary cress infestations were made in 1988. Counts of vertical root extensions and shoots were taken.

Differences in shoot density were determined by analysis of variance with mean separation by least significant difference $(\mathrm{P} \leq 0.05)$. Precipitation and growing degree day estimates were determined bimonthly for the months of March, April, and May during the period of 1987-1994. Stepwise linear regressions (Statsgraphics, Cambridge, Mass.) were performed to select the periods of precipitation and growing degree day accumulation that accounted for the variation in annual shoot density.
Germination was greatest on the toe slope with minimal soil coverage. Germination at the other topographic positions improved with some seed burial. Microand macro-topographic characteristics influence seed germination (Harper 1983). These influences largely reflect the degree of contact between the seed and soil surface and the matric potential of the soil water (Fenner 1985). Osmotic potential can also be a factor, especially in arid areas where salt influences are more common. Kiemnec and Larson (1991) reported hoary cress germination rates of $82,55,11$ and $0 \%$ at osmotic potentials of $0,-0.5,-1.0$, and $-1.5 \mathrm{MPa}$. The process of soil freezing and thawing may have also benefited germination through vertical redistribution of soil moisture upward toward the freezing layer (Heidmann and Thorud 1976). In finer textured soils, freezing and thawing can increase moisture levels at the soil surface to near saturation (Krumbach and White 1964, Harlan 1973). We speculate that some or all of these processes were present during our study and likely contributed to the pattern of field germination.

Seed germination (field + lab) achieved rates of 71 to $94 \%$. Compared to field germination these germination rates suggest 
Table 2. Hoary cress emergence in 2 plant communities with 2 levels of seedbed preparation.

\begin{tabular}{llcc}
\hline \hline Year & Seedbed & \multicolumn{2}{c}{ Community } \\
& & Sagebrush & $\begin{array}{c}\text { Annual } \\
\text { Grass }\end{array}$ \\
\hline 1987 & & $--\left(\text { shoots } 0.2 \mathrm{~m}^{-2}\right)^{1}---$ \\
& tilled & $0.68 \mathrm{a}$ & $14.68 \mathrm{~b}$ \\
& undisturbed & $0.0 \mathrm{a}$ & $0.0 \mathrm{a}$ \\
1988 & & & \\
& & & \\
& tilled & $3.32 \mathrm{a}$ & $9.32 \mathrm{~b}$ \\
& undisturbed & $0.0 \mathrm{a}$ & $0.0 \mathrm{a}$ \\
\hline
\end{tabular}

${ }^{\mathrm{T}}$ Horizontal letter changes within each year indicate significance $(\mathrm{P} \leq 0.05)$

that moisture and/or temperature rather than seed viability or dormancy were limiting germination in this study.

\section{Emergence}

Seedling emergence occurred only on plots that were tilled and was greatest in the annual grass community (Table 2). None of the seedlings that emerged during the study survived beyond May. This was likely due to a lack of available soil moisture.

\section{Vegetative reproduction}

Shoot density fluctuations occurred within monitored hoary cress populations. Shoot densities ranged from 12 shoots $0.2 \mathrm{~m}^{-2}$ (1989 and 1993) to 5 shoots $0.2 \mathrm{~m}^{-2}$ (1990 and 1994). These changes did not result in a measurable expansion or contraction of the area occupied by the hoary cress populations. Hoary cress seedlings were observed in the monitored populations in 1989 and 1993, but did not survive beyond their first growing season (data not shown).

Excavations of hoary cress showed the creeping root system averaged 19 vertical extensions arising from lateral roots and each extension averaged 2.5 shoots with numerous dormant buds. These excavations suggest that the creeping root system is the primary source of the observed density fluctuations.

Precipitation amounts and the number of accumulated growing degree days during 16-30 April and 1-15 May accounted for $76 \%\left(\mathrm{R}^{2}\right)$ of the observed variation in shoot density (Table 3 ). Precipitation (44\%) and accumulated degree days (22\%) for April 16-30 contributed 66\% of the $\mathrm{R}^{2}$ value. Precipitation $(22 \%)$ and accumulated degree days (12\%) for May $1-15$ contributed the remaining $34 \%$ of the $\mathrm{R}^{2}$ value.
Table 3. Regression model of shoot density association with precipitation amount and accumulated degree days in 16-30 April and 1-15 May during the period 1987-1994.

\begin{tabular}{lccc}
\hline \hline Variable $^{1}$ & $\begin{array}{c}\text { Coefficient } \\
(\mathrm{b})\end{array}$ & t-value & $\mathrm{P}$ \\
\hline Intercept (a) & 17.14 & 5.20 & 0.01 \\
Degree Day & & & \\
16-30 April $\left(\mathrm{X}_{1}\right)$ & -0.12 & -4.82 & 0.01 \\
1-15 May $\left(\mathrm{X}_{2}\right)$ & 0.09 & 3.25 & 0.01 \\
Precipitation; $\mathrm{cm}$ & & & \\
16-30 April $\left(\mathrm{X}_{3}\right)$ & -2.68 & -5.04 & 0.01 \\
1-15 May ( $\left.\mathrm{X}_{4}\right)$ & 1.22 & 4.01 & 0.01 \\
\hline${ }^{1}$ Regression model: $\mathrm{Y}=\mathrm{a}+\mathrm{b}_{1} \mathrm{X}_{1}+\mathrm{b}_{2} \mathrm{X}_{2}+\mathrm{b}_{3} \mathrm{X}_{3}+\mathrm{b}_{4} \mathrm{X}_{4}$ \\
${ }^{2}$ Growing degree day $=\frac{\text { max temp }+ \text { min temp }- \text { threshold }}{2}$
\end{tabular}

Precipitation and degree day accumulation for 16-30 April were negatively associated with shoot density (Table 3 ). Precipitation and degree day accumulated during the first half of May were positively associated with shoot density. These relationships suggest cool, dry weather in the later half of April and/or warm, moist conditions in the first half of May are associated with years of increased hoary cress density.

We speculate that rapid above ground growth in April is susceptible to frost or drought damage in May. In 1990, warm, moist conditions in April were followed by frost damage from 5 nights below freezing in May. These cold conditions were associated with a $56 \%$ reduction in shoot density compared to shoot density in 1987. Low temperatures of $2^{\circ} \mathrm{C}$ or lower occur later than 10 May in 5 out of 10 years and temperatures below $4{ }^{\circ} \mathrm{C}$ occur later than 4 May in 2 out of 10 years. In 1994 , rainfall total was $30 \mathrm{~mm}$ and average temperature (max/min) was $58 / 34^{\circ} \mathrm{C}$ in April. These conditions were followed by below normal $(0.8 \mathrm{~mm})$ early May precipitation and 6 days in which maximum temperatures ranged from 24 to $29^{\circ} \mathrm{C}$. These growing conditions were associated with a $36 \%$ reduction in shoot density.

By contrast a cool, dry April in 1989 and 1993 was followed by several rains (> 6 $\mathrm{mm}$ ) during the first 15 days of May. Mean daily maximum temperatures in May both years was near $18^{\circ} \mathrm{C}$ and lows were above $1^{\circ} \mathrm{C}$. These conditions were associated with 31 and $41 \%$ increases in shoot density.

\section{Implications}

Hoary cress germination is limited by dry environmental conditions (Kiemnec and Larson 1991). The xeric nature of the sagebrush ecosystem restricts seed germi- nation, emergence, and survival to microsites where moist conditions are present. These conditions most likely occur on toe slope positions and soil disturbance areas where direct seed-to-soil contact is maximized. Reproduction by seed occurred 2 out of 8 years and was associated with warm, moist weather in May.

Shoot densities in established hoary cress populations vary annually. Densities are increased by early cool, dry periods followed by warmer, wetter conditions and decreased by frost or drought damage. Measured changes, however, did not result in a measurable expansion or contraction of hoary cress populations.

We speculate that the spread of hoary cress, controlled primarily by environmental conditions, is occurring at a relatively slow rate. Soil moisture conditions needed for seed germination occur relatively infrequently. However, established plants appear to readily sequester resources via a creeping root system thus reducing the risk of shoot mortality. Factors such as irrigation, disking established populations, foraging by pocket gophers, and other influences that increase soil moisture or fragmentation of existing root systems will tend to increase the rate of spread.

\section{Literature Cited}

Bellue, M. K. 1946. Weed seed handbook. Series VI. Calif. Dept. Agr. Bull. 22:288.

Daubenmire, R. 1970. Steppe vegetation of Washington. Washington Agr. Exp. Sta. Tech. Bull. No. 62.

Dowdy, S. and S. Wearden. 1983. Statistics for research. John Wiley \& Sons. New York.

Fenner, M. 1985. Germination. p 87-102. In Seed Ecology. Chapman \& Hall. New York.

Groh, H. 1940. Hoary cresses in Canada. Sci. Agr. 20:750-756.

Harlan, R.L. 1973. Analysis of coupled heatfluid transport in partially frozen soil. Water Resour. Res. 9:1314-1323.

Harper, J.L. 1983. The natural dynamics of plant populations. p. 515-646. In: Population Biology of Plants. Academic Press Inc., London.

Harper, J.L., and R.A. Benton. 1966. The behavior of seeds in soil, part 2. The germination of seeds on the surface of a water supplying substrata. J. Ecol. 54:151-166.

Heidmann, L.J. and D.B. Thorud. 1976. Controlling frost heaving of ponderosa pine seedlings in Arizona. USDA Forest Serv. Res. Pap. RM-172. Rocky Mt. For. Range Expt. Sta., Fort Collins. Colo.

Kiemnec, G. and L. Larson. 1991. Germination and root growth of two noxious weeds as affected by water and salt stresses. Weed Technol. 5:612-615. 
Krumbach, A.R. Jr., and D. P. White. 1964. Moisture, pore space, and bulk density changes in frozen soil. Soil Sci. Soc. Amer. Proc. 28:422-425.

Laird, W.E., M.H. Fillmore, G.D. Macdonald, and D.P. Christenson. 1988. Soil survey of Baker County area, Oregon. USDA, Natural Resources Conservation Service. US Gov. Print. Office, Washington, DC.
Miller, R.W. and R.L. Donahue. 1990. Soils: An introduction to soils and plant growth. Prentice Hall. New Jersey.

Mulligan, G.A. and J.N. Findlay. 1974. The biology of Canadian weeds. 3. Cardaria draba, C. chalepensis, and C. pubescens. Can. J. Plant Sci. 54:149-160.

Mulligan, G.A. and C. Franklin. 1962. Taxonomy of the genus Cardaria with particular reference to the species introduced into North America. Can. J. Bot. 40:1411-1425.
Pryor, M.R. 1959. Hoary Cress: new control findings. Calif. Dept.Agr. Bull. 48:11-14.

Selleck, G.W. 1965. An ecological study of lens and globe-podded hoary cresses in Saskatchewan. Weeds. 13:1-5.

Whitson, T., L. Burrill, S. Dewey, D. Cudney, B. Nelson, R. Lee, and R. Parker. 1992. Weeds of the west. University of Wyoming. Laramie, Wyo.

\section{International Center for Agricultural Research in the Dry Areas (ICARDA) RANGE/FORAGE SCIENTIST/ECOLOGIST VACANCY ANNOUNCEMENT}

\section{Arabian Peninsula \\ The Organization}

ICARDA is a non-profit international agricultural research center in a worldwide consortium of 16 centers, supported by the Consultative Group on International Agricultural Research (CGIAR). The CGIAR is co-sponsored by the World Bank, the Food and Agriculture Organization of the United Nations, the United Nations Development Programme and the United Nations Environment Programme. With a staff of over 400 scientists and support personnel, representing more than 40 nationalities, ICARDA addresses two key areas of agricultural research: germplasm improvement (cereals and legumes) and natural resource management.

\section{The Position}

ICARDA wishes to recruit a dynamic Range Ecology/Forage/Management Scientist to work as part of ICARDA's Arabian Peninsula Regional Program (APRP) whose main office is located in Dubai, UAE. The overall objective of the position is the development of integrated range/forage/livestock production systems and management practices for rangeland regeneration, through conservation and sustainable management of rangeland vegetation and the production of stress tolerant and water use efficient forage crops. In collaboration with the Range Management Scientist at ICARDA headquarters, the incumbent will be responsible for the execution of the research strategy of the rangeland program, which will focus on the following: collection and evaluation of indigenous and exotic forage and rangeland species for the purpose of rangeland regeneration (restoration and rehabilitation) and as sources for alternative forage crops; identification of the appropriate technical options for forage seed/crop production in different agroecological zones in the region; identification of the appropriate technical options for the regeneration of degraded rangelands; adoption and demonstration of rangeland management practices in target areas and pilot sites.

\section{Required Qualifications \& Experience}

- $\mathrm{PhD}$ in Range Science/Ecology, or related discipline, with strong background and scientific experience in range plant ecology and forage production in arid and salt-affected environments. Knowledge of animal/plant interactions and ecophysiology is important.

- Minimum of five years' experience, preferably with knowledge of the region and with international research organizations, demonstrated field orientated skills, and ability to work in an inter-disciplinary team.

- Statistical skills to analyze range dynamics-including overgrazing.

- Ability to communicate in spoken and written English (knowledge of Arabic is desirable).

For further information about ICARDA, the position, terms of appointment, living in UAE and application procedure, please see our website: http://www.cgiar.org/icarda

\section{Application}

Qualified applicants are invited to send: a cover letter of interest, including recent salary history; curriculum vitae; names, addresses, fax and e-mail information for three professional referees,

to: Personnel Office, ICARDA, P.O. Box 5466, Aleppo, Syria

Telephone: (963-21) 2213477, 2225112, or 2225012

Fax: $\quad$ (963-21) 2213490, 2225105, or 5744622

E-mail: ICARDA-JOBS@CGIAR.ORG

(If sending by e-mail, please send documents in Rich Text Format and do not include graphics or other large file attachments.)

REFERENCE: quote INT/0019/00 on the application (or in the subject line if applying by e-mail).

APPLICATION DEADLINE: Applications must be received by 30 September 2000.

ICARDA is an equal opportunity employer, and encourages applications from women. 